\title{
THE FORMATION OF STUDENT`S ECOLOGICAL OUTLOOK - METHODS OF EXPLORATION (EXPERIENCE OF AGRICULTURAL UNIVERSITIES)
}

\author{
Natalya Demeshkant \\ Scientific and Methodic Center of Agrarian Education, Kyiv, Ukraine
}

\begin{abstract}
The formation of harmonic relations between nature and a society implies upbringing of the community members as well as adoption of the behavior patterns with emphasis on a modern ecological outlook. Therefore we have introduced methods of exploration and promotion of different levels of the student's ecological outlook. The experiment included seminars, discussions, surveys, and ecological education of both students and instructors of the Ukrainian Agricultural Universities.
\end{abstract}

Key words: ecological outlook, ecological education, future specialist-agrarian.

Principles of a scientific philosophy of life (outlook upon life) are being formed mostly during the process of an effective transmission of the quality of ecological education. The relationship between man and nature, which is in the center of interest of modern ecological studies, is one of the fundamental principle of the human attitude and development of human thinking, as well as an objective base of the historical formation of a healthy philosophy of life.

Global ecological problems (biosphere changes, environmental contamination, etc.) resulted in the formation of radical changes in the relationships between the man and nature. Today, we have a paradoxical situation, in which several major aspects of human existence, and the existence of a single active man as a part of nature, are in dialectical inconsistency. In the modern times this kind of inconsistency reveals a specific conflict feature, since technological, destructive impact on the nature is critical, and threatens both biosphere and human civilization. Therefore, in such conditions, enhancing the significance of philosophy of life is critical in essence of human being and a society existence. "The society adapts to the ecological requirements first by education (in its broad understanding), then by economy, technology, and law. Philosophical function of ecology relies on transformation of personal values, convictions, ideas, expectations, and everything which determines the structure of human philosophy of life" (Drobnochod, 2000).

Ecology is related to the scientific outlook upon life by a countless number of different connections. The ecological reality contributes to the part of a scientific view of the world. Ecology as a science keeps changing by acquiring more of human dimensions, and by its study strategies approaches close to many humanistic disciplines. Otherwise, it would not be possible to use such cognitive concepts as biosphere, agrocenosis, or urban ecosystem, transformed by human activities. In the framework of methodological and sociocultural arsenal of ecology, many unseen thus far categories appear, including obligations, welfare, and good deeds. Just on the level of philosophy of life, we can see the strongest signs of the process of ecology humanization, as well as ecologization of other scientific disciplines; science ecologization, understood as assuming a continuous and serious attitude toward the entire environment, with no acquiescence to technology and/or inanimate nature. It is most visible in an anxiety for life motivated by well-known humanist of our century Svajcer A.: "Only the absolute and common purposeful behavior and life development are ethical, and this is the aim of ethical anxiety for life. Any other necessity is unethical" (Sveicer, 1973).

An idea of a continuously growing influence of human impact on the natural environment was formed at the beginning of XX century. This kind of thinking has been clearly expressed for the first time in the published works of an American scientist C. Szuchert and a Russian professor A. Pawlow (Wernadski, 1975).

According to presented herein concept, a very important factor is that acceleration of technological development in modern times requires establishing some basic philosophical 
orientations, as well as changing of complicated and continuously forming outlooks upon relations between man and nature throughout the centuries. "Today's full of miracles and antagonisms phase of advance, while making gifts to society, at the same time has changed our little universe very deeply, and challenged the human being by unheard-of tasks, also implicating unpredictable disasters... By giving us a gift of unimaginable strength, and by making us accustomed to the standards of living that we couldn't dream this up before, at the same time the scientific and technological progress does not warrant a practical wisdom to control our possibilities" (Peczeji, 1985).

The prime outlook upon life is a system consisting of the most common conceptions of life and views of surrounding world and our position in nature. A Russian scientist W. Szynkaruk described the prime concept of outlook upon life as a form of social selfconsciousness, which is being formed thorough the system of concepts and ideas existing in the society, and reflects the specified views of people's life. However, when these aforementioned conceptions reach the specific net concepts, they are converted to the outlook upon life, and most of all, to the relation man-world. This relationship specifies a man's world-attitudes. The net concepts represent a core surrounded by ideas of world and man. Moreover, these ideas are forming a base for the specific philosophy of life (Szynkaruk, 1978).

The major idea, in the context of our study, is evaluation of the influence of multiaspect ecological factors and development of an outlook upon life in modern, future specialist who is educated at the universities. Just an analysis of the prime outlook upon life trends in the modern ecology allows for a detailed observation of our developing relations with nature. It appears that Kant's question: "How to find a place in the world and properly understand who to be a man?" is still current.

Formation of harmonious relations between nature and society needs the proper education of personalities with the modern ecological outlook.

As experience shows, such primary directions of education are used for today, as introduction of the special courses is from the bases of conservancy in on-line tutorials, teaching the obligatory courses on the protection of environment and saving of resources in higher educational establishments of different levels of the accreditation. However, as an analysis testifies, this it is not enough for forming ecological students' outlook. Forming active vital position is a leading idea with hard persuasion to act, a development of skills of concrete practical activity on the protection of nature and environment.

In the structure of ecological outlook of future specialist-agrarian the cognitive criteria becomes separated from emotional-motivation and behaviour-activity components. That is, by affecting development of noted constituents of ecological outlook, it is possible to increase the level of its formation as a whole. Therefore the pointed constituents were selected in the criterion of the formation of ecological outlook.

These criteria and proper to them indexes are given in table 2. On their basis the three levels are selected to form the ecological students' outlook (table 1). The mentioned levels turned out by means the supervisions, questionnaires, tests, control works.

Table 1. Criteria and indexes of the formation of ecological students' outlook

\begin{tabular}{|c|c|}
\hline Criteria & Indexes \\
\hline Cognitive & $\begin{array}{c}\text { I - notion about ecology as a science (its subject, task, leading ideas); } \\
\text { - understanding ecological problems of global and regional character; } \\
\text { - knowledge of basic principles of nature protection and resources-economy } \\
\text { activity; } \\
\text { II - presence of interest to the study of ecological questions, necessity in } \\
\text { deepening the knowledge }\end{array}$ \\
\hline
\end{tabular}




\begin{tabular}{|c|c|}
\hline Emotional-motivational & $\begin{array}{c}\text { I - ability to be oriented on spiritual values common to all human, in that } \\
\text { number on a health how a value is; moral motivation of environmental } \\
\text { protection; }\end{array}$ \\
$\begin{array}{c}\text { II - disturbance by the state of environment and level of population mobility; } \\
\text { - self-appraisal and estimation of conduct of others in relation to the nature, } \\
\text { your health and heals of surrounders. }\end{array}$ \\
\hline Behavior -activity & $\begin{array}{c}\text { I - abilities and skills of correct behavior in nature, environment; observance } \\
\text { of them in everyday life; } \\
\text { II - application of the acquired ecological knowledge in professional activity. }\end{array}$ \\
\hline
\end{tabular}

Table 2. Levels of formed of ecological students outlook

\begin{tabular}{|c|c|c|c|}
\hline \multirow[t]{2}{*}{ Criteria } & \multicolumn{3}{|c|}{ Levels and indexes of formed of ecological students outlook } \\
\hline & high & middle & low \\
\hline Cognitive & $\begin{array}{l}\text { I - has notion about } \\
\text { ecology as a science; } \\
\text { understands the } \\
\text { ecological problems of } \\
\text { global and regional } \\
\text { character; knows basic } \\
\text { principles of nature } \\
\text { protection and resources- } \\
\text { economy activity; } \\
\text { II - presents firm interest } \\
\text { in the study of ecological } \\
\text { questions, needs in } \\
\text { deepening of knowledge. }\end{array}$ & $\begin{array}{l}\text { I - has shallow knowledge } \\
\text { about ecology as science; } \\
\text { knows its object, basic tasks, } \\
\text { but is oriented in the leading } \\
\text { ideas of it; has notion about } \\
\text { ecological problems, but don't } \\
\text { understand the reasons of } \\
\text { their origin; names 1-2 prin- } \\
\text { ciples of nature protection and } \\
\text { resources-economy activity; } \\
\text { II - professes interest to the } \\
\text { study of ecological questions. }\end{array}$ & $\begin{array}{l}\text { I - understands ecology } \\
\text { only as conservancy, } \\
\text { does not know its object, } \\
\text { basic tasks, leading } \\
\text { ideas; knows about } \\
\text { existence of ecological } \\
\text { problems but names only } \\
1-2 \text { of them; don't } \\
\text { understand reasons of } \\
\text { their origin; } \\
\text { II - does not professes } \\
\text { interest to the study of } \\
\text { ecological questions. }\end{array}$ \\
\hline & $\begin{array}{l}\text { I- orientated in common } \\
\text { to all human values and } \\
\text { among them named } \\
\text { health; present motiva- } \\
\text { tion of environmental } \\
\text { protection; } \\
\text { II - exposes a } \\
\text { disturbance by the state } \\
\text { of environment and level } \\
\text { of morbidity, but not } \\
\text { always adequately } \\
\text { estimates yourself } \\
\text { behavior and behavior of } \\
\text { other in relation to } \\
\text { nature and health. }\end{array}$ & $\begin{array}{l}\text { I - orientated more on con- } \\
\text { sumer attitude toward nature; } \\
\text { on a health the population } \\
\text { accepts fact of influencing of } \\
\text { contamination of environ- } \\
\text { ment, but environmental } \\
\text { motivation is absent; } \\
\text { II - exposes a disturbance by } \\
\text { the state of environment and } \\
\text { level of disease of population, } \\
\text { but not always adequately } \\
\text { estimates yourself behavior } \\
\text { and behavior of other in } \\
\text { relation to nature and health. }\end{array}$ & $\begin{array}{l}\text { I - don't interest in the } \\
\text { consequences of influen- } \\
\text { cing of contamination of } \\
\text { nature on a health; the } \\
\text { environmental } \\
\text { motivation is absent; } \\
\text { II - indifferently behaves } \\
\text { to ecological } \\
\text { problems and to the level } \\
\text { of disease of population; } \\
\text { mostly can not adequa- } \\
\text { tely estimate yourself } \\
\text { behavior and behavior of } \\
\text { other in relation to nature } \\
\text { and health. }\end{array}$ \\
\hline $\begin{array}{l}\text { Behavior- } \\
\text { activity }\end{array}$ & $\begin{array}{l}\text { I - has abilities and } \\
\text { skills of correct } \\
\text { behaviour in nature, } \\
\text { environment, adheres to } \\
\text { them in everyday life; } \\
\text { II - understands a } \\
\text { necessity in application } \\
\text { of ecological } \\
\text { knowledge's in } \\
\text { professional activity. }\end{array}$ & $\begin{array}{l}\text { I - has some abilities and } \\
\text { skills of correct behaviour in } \\
\text { nature, but not always } \\
\text { adheres to them in the } \\
\text { everyday life; } \\
\text { II - not always understands } \\
\text { the necessity of application of } \\
\text { ecological knowledge's in } \\
\text { professional activity. }\end{array}$ & $\begin{array}{l}\text { I - has only elementary } \\
\text { abilities of correct beha- } \\
\text { viour in nature, not ad- } \\
\text { hering to them, or adhe- } \\
\text { res to them episodically; } \\
\text { II - do not understand } \\
\text { necessity of application } \\
\text { of ecological knowled- } \\
\text { ge's in professional } \\
\text { activity. }\end{array}$ \\
\hline
\end{tabular}


The presence of interest to professional activity is the obligatory condition of creative attitude of man to labour, therefore we spared special attention to the study of factors, which affect students' interest to environment problem.

Ecological knowledge - it is the product of public development. The systematized ecological knowledge grows into ecological consciousness of people continuously and purposefully in the process of communication with other people, teaching in different educational establishments and that's why it needs a definite structure, noting of information as global so as local character, that allows independently to understand the ecological problems of a different level and take part in their decision.

Practical activity from a protection and improvement of environment is the important element of the formation of students' ecological outlook, that is ecological activity, which requires a deep capture by ecological knowledge, understanding of their practical application.

We consider that ecologically expedient activity is the higher display of ecological consciousness and outlook of personality, by the indication of their formed.

To our opinion, the process of forming of ecological students' outlook of higher educational establishments of the III-IV levels of accreditation of agrarian type of all directions of preparation includes such successive links: ecological knowledge - ecological activity ecological consciousness - ecological outlook.

In the structure of readiness of student to future professional nature conservation activity we pointed out the most important components which are needed to postgraduate student of agrarian higher educational establishment for effective nature conservation activity:

1) ecological consciousness in accordance to which his attitude toward an environment is formed with;

2) a system of ecological knowledge;

3) occupation by abilities of practical application of the acquired knowledge in future professional activity.

Such correlation of components represents the structure of professional and gives a possibility to find out components and indications of his readiness to professional ecological activity.

To the specialists with the high level of readiness for realization of professional ecological activity there is to be inherent high responsibility for the remote consequences of still human activity, civil responsibility for nature: understanding of laws of its development, state. An ability for adopting an adequate decision to eliminate negative impact on the environment. A future specialist for working in the agrarian sphere of production must understand communication of man with nature, impossibility of existence of human without of biosphere.

According to such understanding of tasks of experiment, we defined the basic indications of the formation of elements of ecological outlook They are:

1. interest in ecological problems (i);

2. ecological knowledge $(\mathrm{k})$;

3. willingness to apply the acquired theoretical knowledge in practical activity (w).

To work out the total of establishing experiment we took advantage of the method by Dr Macoeva - the Russian methodist-mathematician (Macoev, 1974). During estimation of individual qualities of student, he offered to take into account three indications: viz. interest to the object (i), power (p), capacity (c) and to consider them at three levels.

We used this idea and took indications accordingly: interest to the ecological problems, the acquired ecological knowledge, willingness to apply it in practice. Each of these components considered at three levels, and components are combined on the three in different combinations. At drafting of possible connections 27 variants appear for every level, and only 81 different combination written down in four categories of students, that is characterized by the definite levels of the explored qualities: from the greatest to lowest levels. 
Determination of levels of formation in the students of the explored qualities was conducted by means the questionnaire, which was carried out among the groups of students homogeneous in age and speciality occupied.

Questionnaires were contained on 11 questions, on some of which was offered for the choice from the three to five variants of answers. The questions of questionnaire form group according to three explored qualities.

In particular, presence of interest to the ecological problems at students, turned out with the help of such questions:

1. Do the questions of global and local ecological problems interest you?

2. Which exactly ecological problems fluster you, as a future worker of agriculture?

3. Do you known the influencing of contamination of nature on the health of population? interest:

Depending on that, what answers from offered was select, we defined three levels of high, middle and low.

Do students have ecological knowledge's, we determined through answers for such questions:

1. What basic sources of environmental contamination you know?

2. What most affects the awareness by you ecological problems?:

2.1 The state of environment of our region (cities, villages);

2.2 Mediums of communication;

2.3 Educational process;

2.4 The personal impression about the ecological state in those regions of country, where I visited.

3. Is ecological education necessary for you as to the future workers of agriculture.

4. Do you consider it is necessary to have ecological knowledge's, explain the reasons?

4.1 For common development;

4.2 It is one of terms of healthy way of life;

4.3 To understand the ecological state independently;

4.4 As these knowledge's are included to the curriculum of objects, which I study;

4.5 Ecological knowledge's are needed to me for future professional activity.

5. Do you consider it necessary for some themes professional-oriented disciplines to connect with the subject "Basis of ecology"?

The third, last group of questions allowed to us to draw conclusions in relation to a behavior-activity criterion: activity:

1. What is to your opinion is decisive direction of improvement of resources-economy

1.1 Application of front-rank technologies;

1.2 Transition from administrative to the economic methods of management by resources-economy activity;

1.3 More close co-operation of Ukraine with all countries and international organizations.

2. Do you consider you it is necessary to link economic activity ecological requirements?

3. Is it possible to consider that your future profession needs knowledge's on the questions of management by environment?

As a result of conducting of questionnaire we got data after three indication (by qualities) of the state of ecological students preparation: presence of interest to the ecological problems, knowledge's for the decision of ecological questions, readiness to practical actions in the direction of improvement of ecological situation. 
Our investigations have shown that almost $60 \%$ of students are interested in ecology. They know about the effect of environmental pollution on the human health. Almost $50 \%$ of students interviewed regarded ecological knowledge as indispensable.

Therefore, there are good conditions for the formation of ecological outlook of agrarian specialists in agricultural universities. Clear interest of students in ecological problems should be regarded as an important factor in student's ecological education.

We regret to say that no action is taken to introduce ecological education in universities. It is because there are no programs, educational methodology, literature and other sources of information.

Methodology should contain requirements on the relationships between ecological knowledge and professional knowledge. It should also contain information on practical abilities. Conceptual rules, forms and methods of practical action should also be included in this program. Recommendations on methodology should be included to educational programs and plans of the formation of agrarian specialists. It is important to explain the necessity of these programs for the theoretical and practical preparations of courses.

We would like to point out that ecological education and all forms of practicals should be strictly linked to the rational management of biological resources and nature conservation.

\section{References}

Макоев А.3. (1974). Первое приближение $к$ индивидуализации процесса обучения. Орджоникидзе: Изд-во «Ир», , 219 с.

Дробноход M.I. та інші. (2000). Концептуальні основи формування екологічного мислення та здібностей людини, будувати гармонійні відносини з природою: Монографія / М.І. Дробноход, Ф.В. Вольвач, С.Г. Іващенко. Киев: МАУП, 75с.

Кант И. (1964). Приложение к «Наблюдениям над чувством прекрасного и возвышеного». Соч.: В 6 т./ Под общей ред. В.Ф. Асмуса. Москва: Мысль, Т.2, 510 с. $312 \mathrm{c}$.

Печчеи А. (1985). Человеческие качества: Пер. с англ.. О.В. Захарова. Москва: Прогресс,

Вернадский В.И. (1975). Размышления натуралиста: В 2-х кн. Москва: Наука, Кн. II: Научная мысль как планетное явление, $191 \mathrm{c}$.

Швейцер А. (1973). Культура и етика: Пер. с нем. Москва: Прогресс, 344с.

99.

Шинкарук В.И. (1978). Мировоззрение, наука и философия. Философия науки, №1, С.96 -

Received 18 June 2007; accepted 30 August 2007

Natalya Demeshkant

Scientific and Methodic Center of Agrarian Education, Ministry of Agrarian Policy, Kyiv, Ukraine

11 Smilyanska Street, Kyiv, Ukraine, 03151.

E-mail: demesh@smcal.kiev.ua 